\title{
POLITIK HUKUM PENYELESAIAN KONFLIK BERBASIS AGAMA DI INDONESIA
}

\author{
Ansori dan Muwaffiq Jufri \\ Fakultas Hukum Universitas Islam Madura dan Yayasan Peradaban \\ Nuswantara
}

ABSTRACT

The Constitution and other legislation have guaranteed the upholding of religious freedom, but there are still acts of violation of religious freedom that lead to conflicts that are often found in Indonesia, whether conflict between different adherents or among fellow believers of a religion. It is therefore desirable to have a concept of religious-based conflict resolution to minimize abusive actions. In the provisions of Indonesian legislation, the settlement of religious-based conflicts is regulated in Article 156, and Article 157 of the Criminal Code, as well as in the provisions of Article 2 paragraph (1) of the Presidential Decree No. 1 / PNPS of 1965 on Prevention of Abuse and / or Blasphemy. While the new idea of religious-based conflict resolution that is attempted to offer is by reformulating the authority of religious courts in solving religious conflicts among Muslims, engaging in internal or external religious dialogues and the latter is the da'wah method that focuses on the spirit of tolerance, peace and running religious teachings correctly.

Keywords : Conflict resolution, Religious based

\begin{abstract}
ABSTRAK
Konstitusi dan peraturan perundang-undangan lainnya telah menjamin tegaknya kebebasan beragama, namun masih saja terdapat tindakan pelanggaran kebebasan beragama yang berujung pada konflik yang kerap sekali ditemukan di Indonesia, baik konflik antar penganut agama yang berbeda ataupun antar sesama penganut suatu agama. Oleh karena itu sangat diharapkan adanya konsep penyelesaian konflik yang berbasis agama untuk meminimalisir tindakan-tindakan pelanggaran. Dalam ketentuan peraturan perundang-undangan Indonesia penyelesaian konflik berbasis agama diatur pada Pasal 156, serta Pasal 157 Kitab Undang-undang Hukum Pidana, serta pada ketentuan Pasal 2 ayat (1) Penetapan Presiden Republik Indonesia Nomor 1/PNPS Tahun 1965 tentang Pencegahan Penyalahgunaan dan/atau Penodaan Agama. Sedangkan gagasan baru mengenai penyelesaian konflik berbasis agama yang dicoba untuk ditawarkan ialah dengan reformulasi kewenangan pengadilan agama dalam penyelesaian konflik agama diantara umat Islam, melakukan dialog baik internal agama ataupun eksternal agama dan yang terakhir ialah dengan metode dakwah yang menitikberatkan pada semangat toleransi, kedamaian dan menjalankan ajaran agama secara benar.
\end{abstract}

Kata kunci: Penyelesaian Konflik, Berbasis Agama. 


\section{A. PENDAHULUAN}

\section{Latar Belakang Masalah}

Harus diakui bahwa kebebasan beragama adalah bagian yang tidak terpisahkan dari konsepsi Hak Asasi Manusia (HAM). ${ }^{1}$ Tentang kebebasan berpikir dan mengemukakan pendapat. Pikiran adalah karunia paling berharga yang pernah dimiliki oleh manusia yang telah banyak menentukan arah peradabannya. Pikiran merupakan hasil kerja akal dan kekuatan nalar yang akan menentukan sikap baik dan buruk, benar dan salah. ${ }^{2}$ Karena itu, kebebasan berpikir merupakan sebagian inti dari kemuliaan manusia yang seharusnya menjadi hak seseorang tanpa ada ikatan dan syarat serta hak untuk mengikuti kecenderungan pikiran dan hatinya dalam beribadah dan berkeyakinan.

Selaras dengan pernyataan di atas, jaminan terhadap kebebasan beragama bagi setiap warga negara nyatanya sudah termaktub dalam beberapa pasal UUD 1945. Pasal 28 E ayat (2) UUD 1945 menjelaskan bahwa Setiap orang berhak atas kebebasan meyakini kepercayaan, menyatakan pikiran dan sikap, sesuai dengan hati nuraninya. Pasal ini lebih tegas lagi menyatakan bahwa kebebasan beragama tidak bisa dipisahkan dari kebebasan untuk meyakini kepercayaan, menyatakan pikiran dan sikap sesuai dengan hati nuraninya. ${ }^{3}$

1. Hak Asasi Manusia menurut Pasal 1 ayat (1) UU No. 39 Tahun 1999 adalah seperangkat hak yang melekat pada hakikat dan keberadaan manusia sebagai makhluk Tuhan Yang Maha Esa dan merupakan anugerah-Nya yang wajib dihormati, dijunjung tinggi dan dilindungi oleh negara, hukum, Pemerintah dan setiap orang demi kehormatan serta perlindungan harkat dan martabat manusia.

2 Subhi Mahmassani, Konsep Dasar Hak-Hak Asasi Manusia: Studi Perbandingan Syariat Islam dan Perundang-Undangan Moder., (Jakarta: Litera Antarnusa, 1999). hlm. 99-105.

3 Lihat Pula Ketentuan Pasal 28 E Ayat (1). Menjelaskan bahwa setiap orang bebas memeluk agama dan beribadah menurut agamanya. Kata "setiap orang" berarti "semua orang", tidak membedakan ras, suku, warga Negara mana, dan latar belakang primordial lainnya. Dengan demikian, pasal ini memang ditujukan untuk melindungi hak asasi manusia yang paling asasi, berlaku universal dan lintas batas territorial, adat, budaya, dan perbedaan soaial-politik lainnya. (Lihat Agung Ali Fahmi, Implementasi Jaminan Hukum HAM atas Kebebasan Beragama di Indonesia, hlm. 9). 
Pasal 29 ayat (2) UUD 1945 menegaskan: "Negara menjamin kemerdekaan tiap-tiap penduduk untuk memeluk agamanya masing-masing dan untuk beribadah menurut agamanya dan kepercayaannya itu." Penegasan ini diikuti perintah konstitusi agar negara bertanggung jawab atas pemajuan, perlindungan, penegakan dan pemenuhan hak asasi manusia, baik bagi setiap orang maupun bagi warga negara. Hal ini ditegaskan dalam Pasal 28I ayat (4) UUD 1945 "Perlindungan, pemajuan, penegakan, dan pemenuhan hak asasi manusia adalah tanggung jawab negara, terutama pemerintah." Tentu saja pelaksanaan perlindungan hak asasi manusia ini tidak boleh dilakukan dengan semena-mena, bahkan dengan melanggar hak asasi manusia lainnya. Karenanya, perlindungan ini harus dilakukan dengan tetap memperhatikan prinsip negara yang demokratis.

Terkait dengan kebebasan beragama, Undang-undang Nomor 39 Tahun 1999 ini kembali menegaskan ketentuan UUD 1945, bahwa setiap orang bebas memeluk agama dan menjalankan ibadah menurut agama dan kepercayaannya masing-masing dan, negara menjamin bahwa setiap orang dapat melaksanakan haknya dalam agama tersebut. Pasal 22 ayat (1) menegaskan "Setiap orang bebas memeluk agamanya masing-masing dan untuk beribadah menurut agamanya dan kepercayaannya masing-masing." Sedangkan Pasal 22 ayat (2) menegaskan "Negara menjamin kemerdekaan setiap orang untuk memeluk agamanya masing-masing dan untuk beribadah menurut agamanya dan kepercayaannya itu."

Meski demikian, betapapun konstitusi dan peraturan perundangundangan lainnya telah menjamin tegaknya kebebasan beragama, namun masih saja ditemukan tindakan-tindakan yang melanggar prinsip-prinsip kebebasan beragama. Kondisi tersebut tidak jarang berujung pada konflik, baik antar penganut agama yang berbeda, atupun antar sesama penganut suatu agama. Terkait permasalahan ini, tulisan ini bermaksud mengupas ketentuan hukum mengenai konsep penyelesaian hukum terhadap konflik yang 
disebabkan oleh perbedaan agama dan/atau aliran agama. Tulisan ini juga akan membahasa mengenai alternatif penyelesaian konflik antar umat beragama yang bersumber dari kebiasaan dan/atau tradisi yang berkembang di kalangan masyarakat Nusantara.

\section{Rumusan Masalah}

a. Bagaimana penyelesaian konflik antar agama menurut aturan perundangundangan di Indonesia

b. Bagaimana gagasan konsep penyelesaian konflik berbasis agama di Indonesia.

\section{Tujuan Penelitian}

a. Untuk mengkaji secara mendalam penyelesaian konflik antar agama menurut aturan perundang-undangan di Indonesia.

b. Untuk mengkaji secara mendalam gagasan konsep penyelesaian konflik berbasis agama di Indonesia.

\section{B. PEMBAHASAN}

\section{Penyelesaian Konflik Berbasis Agama Menurut Hukum Positif Indonesia}

Dalam KUHP telah diatur suatu pasal tentang penebaran kebencian dan permusuhan, bahkan dalam Pasal 156, menjelaskan bahwa akan dipidana selama 4 tahun terhadap siapa saja yang melakukan tindak pidana berupa menyebarkan permusuhan, kebencian, dan penghiinaan terhadap golongan lain yang ada di Indonesia. ${ }^{4}$ Ketentuan Pasal 156 KUHP tersebut didukung pula pasal setelahnya, yakni Pasal 157, yang lebih berfokus pada tulisan dan lukisan yang tujuannya untuk menyebarkan kebencian dan permusuhan antar masyarakat atau terhadap golongan masyarakat yang ada di Indonesia, oleh karena alasan tersebut maka pelaku penebar kebencian dapat dipidana selama 2 tahun 6 bulan.

\footnotetext{
${ }^{4}$ Moeljatno, Kitab Undang-Undang Hukum Pidana. 2007. Jakarta: Bumi Aksara, hlm 59.
} 
Berdasarkan beberapa pasal yang ada di KUHP, dirasa hanya pasal inilah yang mencerminkan pembelaan terhadap kaum minoritas yang terhalang dalam menjalankan aktifitas keagamaannya. pasal ini jelasa lebih memidanakan orang atau kelompok yang melakukan tindakan penebaran kebencian serta mengusik adanya permusuhan antar sesame umat beragama.

Bedakan dengan ketentuan pada pasal 156a Kitab Undang-Undang Hukum Pidana. "Dipidana dengan pidana penjara selama-lamanya 5 tahun barang siapa dengan sengaja dimuka umum mengeluarkan perasaan atau melakukan perbuatan":

a. Yang ada pada pokoknya bersifat perusuhan, penyalahgunaan atau penodaan terhadap suatu yang dianut di Indonesia.

b. Dengan maksud agar orang tidak menganut agama apapun juga yang bersindikan Ketuhanan Yang maha Esa."

Selain pada KUHP, aturan mengenai penanggulangan dan penyelesaian konflik berbasis agama dapat ditemukan pada ketentuan Pasal 2 ayat (1) Penetapan Presiden Republik Indonesia Nomor 1/PNPS Tahun 1965 tentang Pencegahan penyalahgunaan dan/atau penodaan agama yang berbunyi "Barang siapa melanggar ketentuan tersebut dalam Pasal 1 diberi perintah dan peringatan keras untuk menghentikan perbuatannya itu di dalam suatu keputusan bersama Menteri Agama, Menteri/Jaksa Agung dan Menteri Dalam Negeri. ${ }^{6}$

Selanjutnya, apabila pelanggaran tersebut dalam ayat (1) dilakukan oleh organisasi atau sesuatu aliran kepercayaan, maka Presiden Republik Indonesia dapat membubarkan organisasi itu dan menyatakan organisasi atau aliran tersebut sebagai organisasi/ aliran terlarang, satu dan lain setelah Presiden

${ }^{5}$ Moeljatno. Kitab Undang-Undang Hukum Pidana. 2007. Jakarta; Bumi Aksara, hlm 59

6. Pasal 1 PNPS Tahun 1965 menjelaskan bahwa "Setiap orang dilarang dengan sengaja di muka umum menceritakan, menganjurkan atau mengusahakan dukungan umum, untuk melakukan penafsiran tentang sesuatu agama yang dianut di Indonesia atau melakukan kegiatan-kegiatan keagamaan yang menyerupai kegiatan-kegiatan keagamaan dari agama itu, penafsiran dan kegiatan mana menyimpang dari pokok-pokok ajaran agama itu." 
mendapat pertimbangan dari Menteri Agama, Menteri/ Jaksa Agung dan Menteri Dalam Negeri.

Sementara itu, terkait dengan Pasal 2 UU Nomor 1/PNPS Tahun 1965, maka tindakan yang dapat dilakukan pemerintah adalah memberi perintah dan peringatan keras untuk menghentikan perbuatannya itu di dalam suatu keputusan bersama Menteri Agama, Menteri/Jaksa Agung dan Menteri Dalam Negeri.

Selanjutnya, jika peringatan keras sudah dikeluarkan dalam bentuk Surat Keputusan Bersama Menteri Agama, Jaksa Agung dan Menteri Dalam Negeri, tetapi pelanggaran masih terus terjadi, berdasarkan Pasal 2 ayat (2) maka Presiden Republik Indonesia dapat membubarkan organisasi itu dan menyatakan organisasi atau aliran tersebut sebagai organisasi/ aliran terlarang, satu dan lain setelah Presiden mendapat pertimbangan dari Menteri Agama, Menteri/ Jaksa Agung dan Menteri Dalam Negeri. ${ }^{7}$

\section{Gagasan Penyelesaian Konflik Berbasis Agama di Indonesia}

Dalam menyelesaikan konflik-konflik berbasis agama hendaklah tidak dengan kekerasan, pembantaian, apalagi dengan pembakaran. Masih banyak cara-cara yang lebih arif yang bisa dilakukan diantaranya seperti :

\section{a. Reformulasi Kewenangan Absolut Peradilan Agama.}

Dalam hal kompetensi peradilan ini, konsep yang coba diwacanakan dalam kesempatan kali ini ialah pemberian kewenangan terhadap pengadilan agama khusus untuk menangani segala kasus yang berhubungan dengan segala hal berkaitan dengan sesat-tidaknya suatu aliran keagamaan atau konflik berbasis agama diantara aliran-aliran Islam.

Adapun yang menjadi alasan atau landasan tentang wacana pemberian kewenangan terhadap pengadilan agama dalam

${ }^{7}$ Syaiful Abdullah, Hukum Aliran Sesat; Kebijakan Penal dan Non Penal dalam menanggulangi Aliran sesat di Indonesia, 2009, Malang; Setara Press, hlm 194. 
memeriksa dan memutuskan segala perkara yang berkaitan dengan sesat atau tidaknya suatu aliran dalam agama islam ialah sebagai berikut :

Pertama, alasan historis yang menjadi asal-usul munculnya peradilan agama. Sebagai lembaga peradilan, pengadilan agama dalam bentuknya yang sangat sederhana berupa tahkim, yaitu lembaga penyelesaian sengketa antara orang-orang islam yang dilakukan oleh para ahli agama, peradilan ini telah lama ada dalam masyarakat Indonesia yakni sejak agama islam datang ke Indonesia. Peradilan agama telah lama berfungsi sebagai sarana pemenuhan kebutuhan dasar penduduk yang memeluk agama Islam dalam beribadah, melaksanakan hukum perkawinan dan dan hukum kewarisan.

Kedua, dalam perekrutan hakim di pengadilan agama syaratsyarat mutlak yang harus terpenuhi ialah :

1) Warga negara Indonesia.

2) Beragama Islam.

3) Bertaqwa kepada Tuhan Yang Maha Esa.

4) Setia kepada Pancasila dan Undang-Undang Dasar 1945.

5) Bukan bekas anggota organisasi terlarang Partai Komunis Indonesia, termasuk organisasi massanya atau bukan seseorang yang terlibat langsung ataupun tak langsung dalam "Gerakan Kontra Revolusi G.30.S/PKI", atau organisasi terlarang yang lain.

6) Pegawai negeri.

7) Sarjana syari'ah atau sarjana hukum yang menguasai hukum Islam.

8) Berumur serendah-rendahnya 25 (dua puluh lima) tahun. 
9) Berwibawa, jujur, adil, dan berkelakuan tidak tercela. ${ }^{8}$

Pada poin $b$ disebutkan bahwa hakim pengadilan agama haruslah beragama Islam, syarat ini tidaklah dimaksudkan untuk menimbulkan adanya diskriminasi, tapi kualifikasi diperlukan agar pencari keadilan yang beragama islam yang datang ke Pengadilan agama merasa mantap hati dan perasaannya melaksanakan ibadah umum berurusan dengan orang yang seagama dengan dia. ${ }^{9}$

Lebih lanjut poin $\mathrm{G}$ mensyaratkan untuk menjadi hakim pengadilan agama haruslah berijazah sarjana syariah atau sarjana hukum yang menguasasi hukum islam. Hal inilah yang menjadi titik poin ketika kewenangan memeriksa dan mengadili setiap perkara bermotif agama yang terjadi antara orang Islam diberikan kepada pengadilan agama. Paling tidak dalam pemberian putusan hakim pengadilan agama tidak semata mendasarkan putusannya terhadap aturan normatif, tetapi juga didasarkan pada ketentuan agama Islam yang dipahami oleh hakim tersebut.

\section{b. Penyelesaian Melalui Musyawarah}

Musyawarah merupakan ajaran luhur budaya bangsa Indonesia, seperti yang telah tercantum dalam sila keempat yang isinya "Kerakyatan yang dipimpin oleh hikmat kebijaksanaan dalam permusyawaratan perwakilan”. Budaya bangsa Indonesia sangat menghargai perbedaan, oleh karenanya semenjak dulu bangsa ini tidak pernah mengenal adanya paksaan terhadap sesuatu apapun, segala bentuk permasalahan akan diselesaikan secara musyawarah mufakat tanpa menyakiti pihak manapun.

\footnotetext{
${ }^{8}$. Pasal 13 ayat (1) Undang-Undang Nomor 7 Tahun 1989 Tentang Peradilan Agama

9. Mohammad Daud Ali, Hukum Islam, Pengantar Ilmu Hukum dan Tata Hukum Islam di Indonesia. (Jakarta; PT. Raja Grafindo. 2007). hlm. 285.
} 
Dalam Islam, musyawarah merupakan solusi terbaik yang dianjurkan Allah dan nabi Muhammad SAW. Allah berfirman : "Maka disebabkan rahmat dari Allah-lah kamu berlaku lemah lembut terhadap mereka. Sekiranya kamu bersikap keras lagi berhati kasar, tentulah mereka menjauhkan diri dari sekelilingmu. Karena itu ma'afkanlah mereka, mohonkanlah ampun bagi mereka, dan bermusyawarahlah dengan mereka dalam urusan itu. Kemudian apabila kamu telah membulatkan tekad, maka bertawakkallah kepada Allah. Sesungguhnya Allah menyukai orang-orang yang bertawakkal kepada-Nya.

(QS. Ali Imran 159). ${ }^{10}$

Abdurrahman Wahid, saat menghadiri simposium bertema Dialogue among Civilization: Toward a Culture of Peace di gedung Perserikatan Bangsa Bangsa pada tanggal 13 Juni 2000 menegaskan pentingnya para tokoh agama memiliki pandangan dan wawasan yang luas serta tidak mencurigai agama lain. Para tokoh agama yang satu hendaknya bisa belajar dari agama lain. Jika ajaran agama dijalankan dengan baik, maka problem masyarakat bisa diatasi. Pemahaman secara sempit dan kaku terhadap agama tertentu diharapkan bisa di atasi melalui pendidikan, dialog, dan toleransi. ${ }^{11}$

pendekatan dengan cara dialog ini terbagi dalam dua termin, yakni dialog denga internal agama, serta dialog dengan eksternal agama, dialog selain merupakan ajaran agama, juga merupakan kearifan budaya bangsa, hal ini tercermin dalam butir-butir pancasila. oleh karenanya pendekatan kultural melalui dialog ini

\footnotetext{
${ }^{10}$ Muzhaf Al-Azhar, Al-Qur'an dan Terjemahannya, Bandung, Penerbit Hilal. hlm 57.

${ }^{11}$ Lihat http//www.kompas.com/kompas-cetak/0006/16/nasional/haru06.htm.
} 
perlu untuk menjadi pertimbangan sebagai solusi dalam penyelesaian konflik berbasis agama.

\section{c. Pendekatan Dakwah}

Sebagaimana yang dijelaskan dalam literatur sejarah, kehidupan beragama mengalami berbagai peristiwa yang justru melenceng dari ajaran agama tersebut, beberapa kejadian tersebut ialah :

1) Tidak pernah luput dari sejarah kekerasan dan perang.

2) Banyak korban yang berjatuhan atas nama agama.

3) Terorisme,

4) Pengusiran umat beragama minoritas,

5) Politisasi agama demi kepentingan sepihak

6) Para ahli agama yang kerap kali keluar dari normanorma agama dan lain sebagainya. ${ }^{12}$

Dalam keadaan seperti di atas, sisi psikologis manusia memimpikan "sang juru selamat". Juru selamat yang bisa membawa manusia ke dalam ketenangan baru, ketika agamaagama yang ada tidak mampu memberikannya. Hal ini berarti, bahwa agama seolah-olah gagal memenuhi jawaban atas masalahmasalah kehidupan dan keinginan-keinginan umatnya. Padahal yang benar adalah, agama telah cukup memberikan rambu-rambu/ tuntunan bagi manusia dalam bersikap, bertindak dan berbuat dalam kehidupannya. Jadi, ada kesalahan umat (terutama kalangan agamawan) dalam menafsirkan, memperaktekkan dan menyampaikan risaalah ajaran-ajaran agamanya. ${ }^{13}$

12 Komarudin Hidayat, Agama-agama Besar Dunia; Masalah Perkembangan dan Interelasi, Makalah disampaikan pada Kajian Agama, Paramadina, 23 Januari 1992, hlm 12.

${ }_{13}$ Sebagai percontohan, akhir-akhir ini banyak para pemuka agama yang lebih asyik mengurusi urusan politik, lebih bergairah dalam usaha bisnis, dari pada mengyomi, membimbing, dan 
Bertitik tolak dari hal demikian, munculnya aliran sesat (agama baru), bukan berarti agama yang patut disalahkan, melainkan umat, terutama kalangan agamawan (orang-orangnya) telah gagal meyakinkan / menyampaikan dakwah pada umatnya. Mereka membutuhkan kejujuran para ulama dan pemimpinnya, bukan hanya ayat-ayat dan janji-janji yang mereka langgar sendiri. Umat membutuhkan perdamaian, bukan cela kelompok dan teror atas kelompok yang lain. ${ }^{14}$

Dalam konteks inilah, umat memerlukan keteladanan, bimbingan,ketika mereka merasa dirinya terpinggirkan, bukan hanya kitab-kitab yang berisi aturan-aturan wajib dan haram. Oleh karena itu, menurut Nasaruddin Umar. ${ }^{15}$ Pada masa yang akan datang, perlu dilakukan pendalaman materi dan metode dakwah, yaitu metode dakwah harus sesuai dengan kondisi obyektif.

Ajaran-ajaran agama, seperti kejujuran, solidaritas dan perdamaian, tiga hal yang sangat tak diacuhkan oleh kaum agamawan sekarang- harus menjadi pijakan dalam ruang-ruang tata kehidupan. Umat tentu membutuhkan sikap-sikap keteladanan dari para ulama untuk menjalankan agama mereka. Bagaimana mungkin seseorang mempertahankan agamanya bila pemuka agama yang seharusnya jadi panutan terjerembap dalam pusaran korupsi, egoisme, dan kekayaan duniawi.

Oleh karena itu, menjawab persoalan tersebut, tentu tak ada cara lain kecuali semua orang yang menganggap dirinya beragama, berusaha memulihkan agama dengan menjadikan agama sebagai

memberikan teladan yang baik bagi para umatnya. tak pelak kondisi ini menyebabkan umat beragam kehilangan tauladan yang bisa menjawab segala persoalan keagamaannya.

14 Syaiful Abdullah, Hukum Aliran Sesat; Kebijakan Penal dan Non Penal dalam menanggulangi Aliran sesat di Indonesia, 2009, Malang; Setara Press, hlm 167.

${ }^{15}$ Sampaikan Pesan Agama Dengan Kondisi Obyektif. www.nu-online.com. 
norma dalam keseharian. Menjadikan agama bukan sekadar ritual, tapi merasukkan norma-norma agama ke jantung kehidupan keseharian manusia, misalnya melalui serangkaian dakwah, baik secara lisan (bil lisan) maupun perbuatan (bil hal). ${ }^{16}$ pesan-pesan agama haruslah disampaikan dengan jalan santun, damai, dan tidak menyulut api permusuhan antar sesame pemeluk agama, antar sesame warga Indonesia.

Terdapat anjuran menarik dari Al-Qur'an tentang startegi penyampaian dakwah. "Ajaklah mereka ke jalan Tuhanmu dengan hikmah dan nasihat yang baik, dan bantahlah mereka dengan cara yang baik, sesungguhnya Rabbmu Dia-lah yang lebih mengetahui tentang siapa yang tersesat dari jalan-Nya, dan Dia-lah yang lebih mengetahui orang-orang yang mendapat petunjuk"

\section{(QS- An-Nahl : 125). ${ }^{17}$}

Pada akhirnya, segala upaya non-yuridis tersebut merupakan implementasi qaidah fiqih dalam upaya menyelesaikan konflik berbasis agama di Indonesia. konflik berbasis agama tidak akan tuntas jiak hanya diselesaikan dengan pendekatan hukum dan perundang-undangan, perlu juga dilakukan dengan pendekatan agama, kearifan local, dialog dan cara-cara lain yang dilakukan tanpa kekerasan. qaidah fiqih tersebut berbunyi "Al Muhafadotu 'alal Qodimis Solih, Wal akhdu bil jadidil ashlah. (Peliharalah

16 Agama apapun namanya, pasti memiliki tujuan sebagaimana terdapat dalam tuntunan ajarannya masing-masing. Untuk mewujudkannya/ merealisasikan tujuan agama, maka, maka setiap umat/ pemeluk agama selalu berusaha untuk menyampaikan ajaran agama melalui bermacam-macam sarana, di antaranya melalui dakwah, misalkan agama Islam

17 Aibdi Rahmat, Kesesatan dalam Perspektif Al-Qur'an. 2007. Pustaka Pelajar,Yogyakarta. hlm 197-198. 
tradisi lama (kebiasaan/ qoidah/ pendapat, cara) yang baik, dan ambillah juga tradisi baru yang baik pula)". ${ }^{18}$

\section{PENUTUP}

\section{Kesimpulan.}

Konsep penyelesaian konflik berbasis agama dalam ketentuan peraturan perundang-undangan Indonesia terdapat pada Pasal 156 serta Pasal 157 Kitab Undang-undang Hukum Pidana, serta pada ketentuan Pasal 2 ayat (1) Penetapan Presiden Republik Indonesia Nomor 1/PNPS Tahun 1965 tentang Pencegahan penyalahgunaan dan/atau penodaan agama.

Gagasan baru mengenai penyelesaian konflik beragama yang dicoba untuk ditawarkan ialah dengan reformulasi kewenangan pengadilan agama dalam penyelesaian konflik agama diantara umat Islam, melakukan dialog baik internal agama ataupun eksternal agama, dan yang terakhir ialah dengan metode dakwah yang menitikberatkan pada semangat toleransi, kedamaian, dan menjalankan ajaran agama secara benar.

\footnotetext{
${ }^{18}$ Abdullah Moenasyik, Aspek Dasar Budaya Masyarakat Madura, Makalah pada dialog “ Mencari Format Baru Gerakan Pemuda Ansor", PAC GP Ansor Klampis, 26 September 2007 hlm 9
} 


\section{DAFTAR PUSTAKA}

\section{A. Peraturan Perundang-undangan}

Kitab Undang-Undang Hukum Pidana (KUHP)

Kitab Undang-Undang Hukum Acara Pidana. (Lembaran Negara Republik Indonesia Tahun 1981 Nomor 76)

Undang-Undang Nomor 39 Tahun 1999 Tentang Hak Asasi Manusia. (Lembaran Negara Republik Indonesia Tahun 1999 Nomor 165)

Undang-Undang Nomor 07 Tahun 1989 Tentang Peradilan Agama. (Lembaran Negara Nomor 49 Tahun 1989)

Undang-Undang Nomor 12 Tahun 2005 Tentang Pengesahan International Covenant On Civil And Political Rights (Kovenan Internasional Tentang Hak-Hak Sipil Dan Politik). (Lembaran Negara Republik Indonesia Tahun 2005 Nomor 119)

Penetapan Presiden Nomor 1/PNPS Tahun 1956 Tentang Pencegahan Penyalahgunaan dan/atau Penodaan Agama. (Lembaran negara republik indonesia tahun 1965 nomor 3.)

Peraturan Bersama Menteri Agama dan Menteri Dalam Negeri Nomor 8 dan 9 Tahun 2006 Tentang Pedoman Pelaksanaan Tugas Kepala Daerah/Wakil Kepala Daerah Dalam Pemeliharaan Kerukunan Umat Beragama, Pemberdayaan Forum Kerukunan Umat Beragama, dan Pendirian Rumah Ibadat.

\section{B. Literatur}

Abdullah Moenasyik, Aspek Dasar Budaya Masyarakat Madura, Makalah pada dialog “Mencari Format Baru Gerakan Pemuda Ansor”, PAC GP Ansor Klampis, 26 September 2007.

Aibdi Rahmat.. 2007Kesesatan dalam Perspektif Al-Qur'an. Yogyakarta; Pustaka Pelajar. 
Agung Ali Fahmi. 2011. Implementasi Jaminan Hukum HAM Atas Kebebasan Beragama di Indonesia. Yogyakarta: Interpena.

Komarudin Hidayat. Agama-agama Besar Dunia; Masalah Perkembangan dan Interelasi, Makalah disampaikan pada Kajian Agama, Paramadina, 23 Januari 1992.

Mohammad Daud Ali. 2007. Hukum Islam, Pengantar Ilmu Hukum dan Tata Hukum Islam di Indonesia. Jakarta; PT. Raja Grafindo.

Muzhaf Al-Azhar, Al-Qur'an dan Terjemahannya, Bandung, Penerbit Hilal

Saiful Abdullah. 2009. Hukum Aliran Sesat; Kebijakan Penal dan Non Penal dalam menanggulangi Aliran sesat di Indonesia. Malang; Setara Press

Subhi Mahmassani. Konsep Dasar Hak-Hak Asasi Manusia: Studi Perbandingan Syariat Islam dan Perundang-Undangan Moder., (Jakarta: Litera Antarnusa, 1999

\section{Media Online}

Muslih Fathoni, Artikel Faham Mahdi Syi'ah dan Ahmadiyah dalam Perspektif, http://www.akhirzaman.info/islam/imam-mahdi/88-faham-mahdi-syiahdan-ahmadiyah-dalam-perspektif-bagian-keempat.html. diunduh pada hari senin tanggal 04 Februari 2012 Jam 05;34 WIB.

Nazarudin Umar. Sampaikan Pesan Agama Dengan Kondisi Obyektif. www.nuonline.com

Catatan Akhir Tahun 2011 Komisi Nasional Hak Asasi Manusia. http://www.komnasham.go.id/images/catatan_akhir_2011.pdf. diakses pada tanggal 17 Januari 2015Jam 11;23.

Catatan KontraS. Hampa Perlindungan Hak Asasi Terhadap Warga Negara http://www.kontras.org/index.php?hal=siaran_pers\&id=1189. Diakses pada hari Sabtu tanggal 17 Januari 2015. Jam 12.03.

http//www.kompas.com/kompas-cetak/0006/16/nasional/haru06.htm. 